\title{
EFFICIENCY OF UTILIZATION OF NITROGEN AND PHOSPHORUS BY YORKSHIRE FOG (HOLCUS LANATUS)
}

\author{
R. S. Scotт
}

A gronomy Department, M assey University, Palmerston N orth*

\section{A. HaRdacre}

Plant Physiology Division, DSIR, Palmerston, N orth

Abstract

Two pot experiments compared the yield response and uptake of $\mathrm{N}$ and $\mathrm{P}$ by five New Zealand, two exotic ecotypes and one bred cultivar of Yorkshire fog and Ruanui perennial ryegrass under varying levels of applied $\mathrm{N}$ and $\mathrm{P}$. One experiment was conducted in a heated glasshouse and the other under controlled climate conditions.

Of the Yorkshire fog strains examined, the bred cultivar 'Massey Basyn' and an ecotype from Rotorua provided highest yields of dry matter. Their superiority was attributed in part to their ability to extract greater amounts of $\mathrm{N}$ and $\mathrm{P}$ from the soil. The former was more efficient under high levels of 'applied $\mathrm{N}$ and the latter under high levels of applied P.

Under two distinct climatic environments, 'Massey Basyn' Yorkshire fog gave similar yields and uptake of $\mathrm{N}$ and $\mathrm{P}$ to Ruanui perennial ryegrass. Under a third climate, with higher temperatures and moisture stress, 'Massey Basyn' outyielded Ruanui. This was associated with a greater ability by 'Massey Basyn' to utilize absorbed P.

\section{INTRODUCTION}

YorkshiRe FOG (Holcus lanatus L.) has been described by Saxby (1956) as "one of the most maligned of New Zealand's common grasses because, in spite of its being regarded as undesirable, a very large proportion of New Zealand's butterfat producing pastures contain a considerable amount of it." There is documented evidence to support this observation in the work of McMeekan and Walshe (1963) in the Waikato, where three dairy cows per hectare were grazed on a sward in which Yorkshire fog was a major constituent. They observed that Yorkshire fog was the main contributor to yield in autumn and winter.

Because of iits presence in untopdressed pasture (Saxby, 1956; Harlan, 1956; O’Connor, 1961; During et al., 1962; Jacques, 1962; Whittet, 1964; Smith, 1972; White et al., 1972; Vartha,

*Present address: Invermay Agricultural Research Centre, Mosgiel. 
1973) Yorkshire fog is generally regarded as a "low fertility" species. An attempt was made by Mile's and Miles (1970) to utilize its tolerance of low fertility. 'They found it promising when sown into heather (Callunetum) sites in NE Scotland. In experiments into the reseeding and topdressing of natural pastures, Yorkshire fog has proved to be one of the most successful introductions in Wales and Scotland (Davies, 1940; Hughes and Nicholson, 1961; Hum, 1964), and in Australia (Anon'., 197 1) . In New Zealand it was included in early oversowings on natural pasture (Burnett, 1927) and the presence of Yorkshire fog today is a reflection of its ability to survive and produce forage under adverse climatic and edaphic conditions.

Recent experimentation in New Zealand provides conflicting evidence on the relative merit of oversowing Yorkshire fog on law fertility hill oountry. Dunbar (1971) found on exposed high altitude subsoils 'that topdressing was necessary for the survival of ten herbaceous species including a bred cultivar ('Massey Basyn') of Yorkshire fog. In the presence of fertilizer he found Yosksbire fog superior to all other species (including "low" and "high" fertility grasses) in their ability to make rapid growth. In another study (Dunbar, 1970) Yorkshire fog showed less vigour than cocksfoot (Dactylis glomerata) in the first season but more ground cover in the third season.

On, moderately topdressed mid-altitude sites in Canterbury, Vartha ( 1973) recorded comparable establishment of 'Massey Basyn' Yorkshire fog and Ruanui perennial ryegrass. White et al. (1972), on the other hand, reported poor establishment of the former compared with other "high fertility" grasses sown on low fertility hill country.

From the foregoing review it is apparent that Yorkshire fog has an ability to survive competitively with indigenous and i ntroduced grass species under both low and high fertility conditions. Other factors apart, this provides evidence of a considerable degree of efficiency in the uptake and utilization of nutrients which could bear further investigation.

Reference has been made to levels of fertility but not to the relative requirements for specific nutrients. Little research has been reported on this aspect. Vartha (1960) showed a lower need for sulphur by browntop than by Yorkshire fcg, while O'Connor (1961) found Yorkshire fog to be more responsive to nitrogen than sweet vernal (Anthoxanthum odoratum) and browntop. In a glasshouse study of 'Massey Basyn' Yorkshire fog on an exposed mountain subsoil, Dunbar and Adams (1972) re- 
corded poor growth in the absence of $\mathrm{N}$ and $\mathrm{P}$ but a very large $\mathrm{N} \times \mathrm{P}$ interaction.

Because of the Paucity of information on the relative nutrient requirements of Yorkshire fog and in view of the promise of high yields and improved palatability following selection (Jacques, 1962), a study of its requirements for $\mathrm{N}$ and $\mathrm{P}$ when grown as a monoculture compared with the requirements of perennial ryegrass was undertaken. Results of this study are presented in this paper.

\section{EXPERIMENTAL}

Two pot experiments are reported here. The first (Experiment A) examined responses in yield and nutrient uptake of eight ccotypes (hereafter referred to as "strains") of Yorkshire fog to varying levels of applied $\mathrm{N}$ and $\mathrm{P}$. This experiment was conducted in a heated glasshouse. The second experiment (Experiment B) measured, responses in yield and nutrient uptake of two strains of Yorkshire fog and four cultivars of perennial ryegrass to varying levels of applied $\mathrm{N}$ under three distinct climatic environments. For the purpose of this report results obtained from the strains of Yorkshire fog will be compared with those of Ruanui perennial ryegrass.

Experiment A

The following treatments were examined in a two replicate $\mathrm{S} \times 3 \times 3$ factorial design:

(a) Strains of Yorkshire fog:

1. 'Massey Basyn' (N.Z. bred)

2. Dipton (N.Z. natural ecotype)

3. Abbotsford (N.Z. natural ecotype)

4. Rotorua (N.Z. natural ecotype)

5. Glen Innes (N.S.W. Tablelands natural ecotype)

6. Almeida de Sayago (Spanish natural ecotype)

7. Stratford (N.Z. natural ecotype)

8. Tara Hills (N.Z. natural ecotype)

Nine germinated seedlings were planted per pot.

(b) Levels of applied P. Phosphorus was applied in solution as sodium dihydrogen phosphate at 10,60 and $180 \mathrm{~kg} P / \mathrm{ha}$ calculated on a superficial basis.

(c) Levels of applied N. Nitrogen was applied as, ammonium nitrate at 0,50 and $100 \mathrm{~kg} / \mathrm{ha} \mathrm{N}$ (calculated on a superficial basis) and reapplied at half the initial rates on days $22,36,47$ and 59. 
Basal dressings of $175 \mathrm{~g} / \mathrm{ha}$ sodium molybdate and $290 \mathrm{~kg} / \mathrm{ha}$ potassium sulphate were applied prior to mixing the nutrient treatments and the soil/sand mixture. On day 61 potassium sulphate was re-applied.

The soil used in both Experiments A and B was a Tokomaru silt loam taken from the 1 to 6 in. profile on a site which had no9 previously received fertilizer application. This soil was air dried and passed through a $1.27 \mathrm{~cm}$ sieve and $1600 \mathrm{~g}$ was mixed with $800 \mathrm{~g}$ of fine sand for each pot.

Glasshouse temperatures were maintained between 10 and 25 " C, with natural lighting being the sole source of illumination. So41 moisture levels were maintained at about the moisture equivalent by daily' watering to weight.

The experiment was commenced on September 26, 1972, and harvested on day 46 and again on day 67 . Roots were washed out and weighed after the final harvest.

\section{EXPERIMENT B}

This experiment compared Ruanui perennial ryegrass amongst other ryegrasses (see above) with two strains of Yorkshire fog selected from among those studied in Experiment A. These were the N.Z. bred cultivar 'Massey Basyn' and a natural N.Z. ecotype from Tara Hills. Nine germinated seedlings were planted per pot.

The above species and strains were compared in a four replicate factorial experiment with five levels of $\mathrm{N}(0,5,10,30$ and $60 \mathrm{~kg} \mathrm{~N} / \mathrm{ha}$ calculated on a superficial basis) applied as ammonium nitrate on days $0,21,31$ and 36 .

The same soil/sand mix and the same basal dressings were used as those described for Experiment A.

Plants were grown in a glasshouse in which temperature was maintained between 15 and 25 " C before being transferred to controlled climate rooms* on day 21 .

The factorial comparison of species/strains and $\mathrm{N}$ levels were made under three simulated climates as shown in Table 1.

Plants were' "harvested on day 52.

\section{STATISTICAL}

Results of both experiments were analysed as orthogonal polynomials in which sensitive comparisons were made between

\footnotetext{
*Cl/mate Laboratory, Plant Physiology Division, DSIR, Palmerston North.
} 
TABLE 1: ENVIRONMENTAL CONDITIONS

\begin{tabular}{|c|c|c|c|c|c|c|}
\hline \multirow{2}{*}{$?$} & & & & \multicolumn{3}{|c|}{ Climate Simulated } \\
\hline & & & & $\begin{array}{l}\text { Tara Hills } \\
\text { (Summer) }\end{array}$ & $\begin{array}{c}\text { Palmerston } \\
\text { North } \\
\text { (Spring) }\end{array}$ & $\begin{array}{c}\text { Taieri } \\
\text { (Winter) }\end{array}$ \\
\hline \multicolumn{7}{|l|}{ Temperature $\left({ }^{\circ} \mathrm{C}\right)$ : } \\
\hline Day & & $\ldots$ & & 22.5 & 15 & 12 \\
\hline Night & .... & $\ldots$. & .... & 7.5 & 10 & 3 \\
\hline Lighting $\left(\mathrm{W} / \mathrm{m}^{2}\right)$ & $\ldots$. & $\ldots .$. & & 150 & 180 & 90 \\
\hline Day length (h) & & & & 14 & 12 & 7 \\
\hline Day/night land night/d & y cl & gear & & 1.5 & 1 & 2 \\
\hline \multicolumn{7}{|c|}{ Vapour pressure deficit $(\mathrm{mb})$ : } \\
\hline Day (\% R.H.) & & ..." & $\ldots$ & $10(60)$ & $5(70)$ & $2(80)$ \\
\hline Night $(\%$ R.H & & & & $3(70)$ & $20(80)$ & $1(90)$ \\
\hline \multicolumn{7}{|c|}{$\mathrm{CO}$, ambient } \\
\hline Soil moisture $(\% \mathrm{mo}$ & stur & quiv & & 80 & 80 & $\begin{array}{l}50 \text { cycling } \\
\text { to } 30\end{array}$ \\
\hline
\end{tabular}

selected species/strains and combinations of them following appropriate transformation of data. Further, the variance due to the difference between these species and strains in their response to $\mathrm{N}$ or $\mathrm{P}$ was partitioned into their linear and quadratic components. This treatment of results, while not enabling comparisons of all species/strains, enabled comparisons of the slope and curvature of the response of some varieties, a useful method of gauging nutrient efficiency.

The selected species/strain comparisons were:

\section{Experiment $A$ :}

1. 'Massey Basyn' versus Tara Hills

2. 'Massey Basyn' and Tara Hills versus the rest

3. North Island versus South Island strains

4. Dipton versus Abbotsford

5. Rotorua versus Stratford

6. N.Z. strains (excluding 'Massey Basyn' and Tara Hills) versus Exotics

7. Glen Innes versus Almeida de Sayago

Experiment $\mathrm{B}$ : In this experiment the yield response and $\mathrm{N}$ and $P$ uptake curves of the strains in most cases either had a common starting point or a common end point. This enabled a simple analysis of variance to be used to distinguish strain differences according to level of $\mathrm{N}$ or $\mathrm{P}$ applied. 


\section{RESULTS}

Experiment A

Mean shoot yields at both harvests, total shoot and shoot + root yields for all strains are presented in Table 2. Differences in total shoot yields are largely a reflection of differences recorded at the first harvest on day 46 where Almeida de Sayago and Tara Hills strains gave lower mean yields than the other strains.

TABLE 2: MEAN YIELDS OF STRAINS OF YORKSHIRE FOG (logarithmic transformation of $\mathrm{g} / \mathrm{pot}$ )

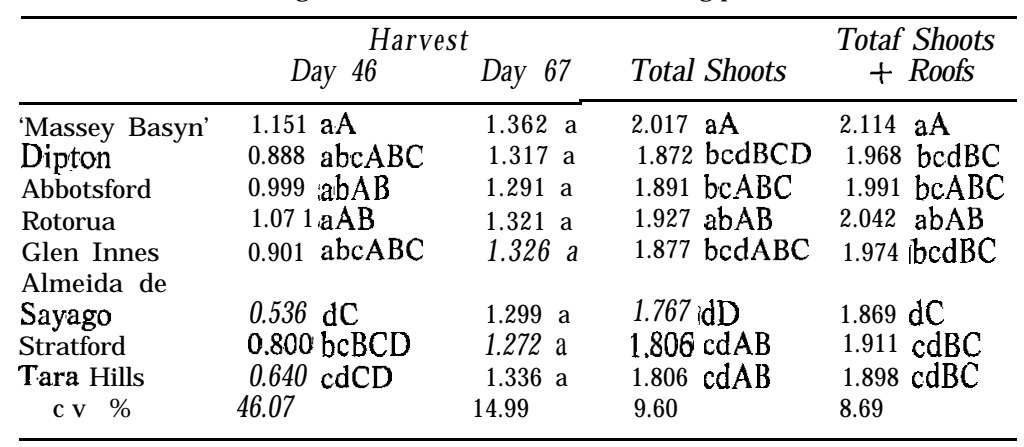

Of the comparisons made of differencces in yield on day 46 'according to level of nutrient applied, Almeida de Sayago and Glen Innes differed significantly $(P<0.05)$ in their response to N. From Fig. 1 (a) it is evident that yields were similar in the absence of applied $\mathrm{N}$ but differed increasingly as the level of $\mathrm{N}$ was increased. Glen Innes responded to applied $\mathrm{N}$, whereas Almeida de Sayago gave no evidence of a response and a clear depression in yield at the highest level of $\mathrm{N}$ application.

There is similarity in the order in which strains can be ranked for total shoot yields and shoot + root yields. 'Massey Basyn' gave higher yields than all 'other strains except Rotorua while Almeida de Sayago, Stratford and Tara Hills strains gave lowest mean yields. In the absence of any linear or quadratic $\mathbf{x} \mathrm{N}$ or $\mathrm{P}$ interactions with strain differences; it can be assumed that the pattern of response of all strains did not differ according to the level of nutrient applied.

The, concentrations of $\mathrm{N}$ and $\mathrm{P}$ in the shoots at both harvests are shown in Table 3. The concentration of $\mathrm{N}$ in the shoots was similar for Dipton, Abbotsford, Rotorua, Glen Innes and Stratford strains. 'Massey Basyn' and Almeida de Sayago contained 
PROCEEDINGS N.Z. GRASSLAND ASSOCIATION
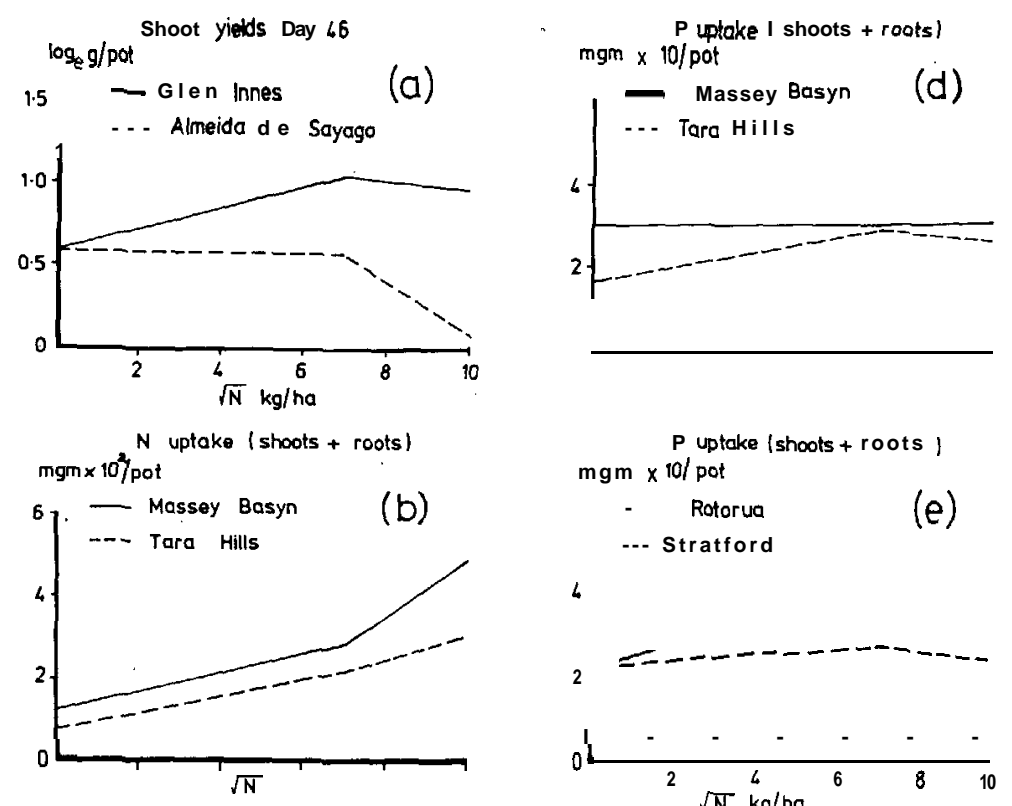

P uptake (shoots + roots ) $\mathrm{mgm} \times 10 / \mathrm{pot}$

$$
\text { - Rotorua }
$$
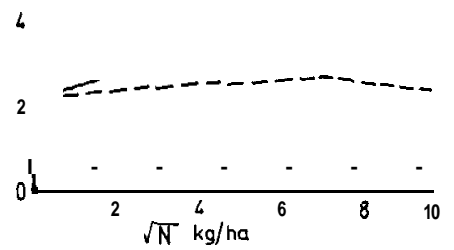

$\mathrm{N}$ uptake (shoots + roots )
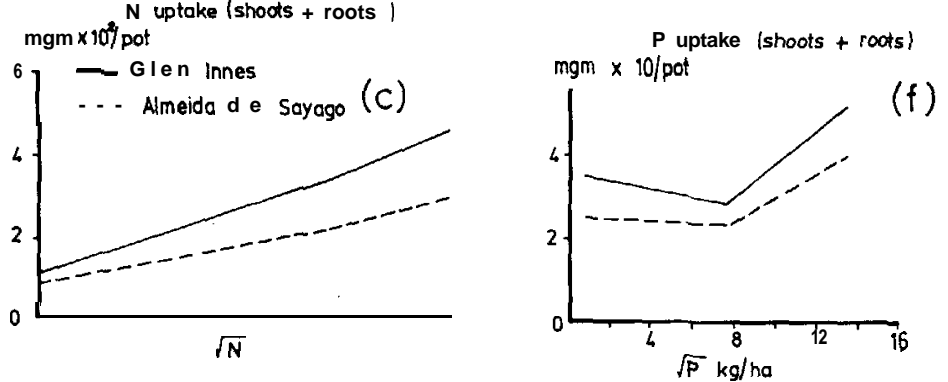

FIG. 1: M ean yield and uptake data for significant strain differences $x$ level of nutrient regressions.

lower concentrations. while the Tara Hills strain had the lowest concentration.

The differences among strains in $\mathrm{P}$ concentration in the shoots varied between harvests. In general terms, 'Massey Basyn', Dipton, Abbotsford, Rotorua and Stratford strains were similar. Glen Innes contained significantly $(\mathrm{P}<0.01)$ lower levels of $\mathrm{P}$ than these at the second harvest, when available $\mathrm{P}$ was lower (as indicated by the lower $\mathrm{P}$ concentrations in herbage at the second harvest). The Tara Hills strain contained low P concentrations at both harvests. 
TABLE 3: MEAN CONCENTRATIONS (\%) OF N AND P IN SHOOTS OF YORKSHIRE FOG ON HARVEST DAYS 46 AND 67

\begin{tabular}{|c|c|c|c|c|}
\hline & \multicolumn{2}{|c|}{$\mathrm{N}$} & \multicolumn{2}{|c|}{$P$} \\
\hline & Day $4 G$ & Day 67 & Day 46 & Day 67 \\
\hline \multicolumn{5}{|l|}{ 'Massey } \\
\hline Basyn’ & $4.39 \mathrm{bcBC}$ & $2.71 \mathrm{cdBC}$ & 0.39 abcABC & $0.38 \mathrm{abAB}$ \\
\hline Dipton & $4.87 \mathrm{aA}$ & $3.03 \mathrm{abAB}$ & $0.41 \mathrm{abABC}$ & $0.39 \mathrm{abAB}$ \\
\hline Abbotsford & $4.73 \mathrm{abAB}$ & $2.75 \mathrm{bcBC}$ & $0.43 \mathrm{aAB}$ & $0.40 \mathrm{aA}$ \\
\hline Rotorua & $4.75 \mathrm{aAB}$ & $2.97 \mathrm{abcAB}$ & $0.44 \mathrm{aA}$ & $0.37 \mathrm{bAB}$ \\
\hline Glen Innes & $5.03 \mathrm{aA}$ & $3.22 \mathrm{aA}$ & $0.41 \mathrm{aABC}$ & $0.32 \quad c C$ \\
\hline \multicolumn{5}{|l|}{ Almeida de } \\
\hline Sayago & $4.22 C C$ & $2.45 \mathrm{deCD}$ & $0.35 \mathrm{bcBC}$ & $0.37 \mathrm{bB}$ \\
\hline Stratford & $4.78 \mathrm{aAB}$ & $2.97 \mathrm{abcAB}$ & 0.39 abcABC & $0.37 \mathrm{bAB}$ \\
\hline Tara Hills & $3.66 \mathrm{dD}$ & $2.27 \mathrm{eD}$ & $0.34 c c$ & $0.38 \mathrm{bAB}$ \\
\hline $\mathrm{cv} \%$ & 11.57 & 15.75 & 22.76 & 10.92 \\
\hline
\end{tabular}

Calculated total $\mathrm{N}$ and $\mathrm{P}$ uptake by shoots + roots is presented in Table 4. The uptake of $\mathrm{N}$ was similar for all strains except Almeida de Sayago and Tara Hills which gave lower values. In the analysis of regression of strain differences $x$ level of N, 'Massey Basyn' and Tara Hills differed in a linear $(P<0.001)$ and quadratic $(P<0.05)$ manner. This effect is shown in Fig. 1 (b) which illustrates an equal uptake of $\mathrm{N}$ for both strains at low levels of 'applied $\mathrm{N}$,but markedly greater uptake by 'Massey Basyn' under high levels of applied N. In a similar type of comparison (Fig. 1 (c) ) Glen Innes showed an increasing ability to extract soil $\mathrm{N}$ compared with Almeida de Sayago as the level of applied $\mathrm{N}$ was increased. This interaction was highly significant $(\mathrm{P}<0.001)$.

$\mathrm{P}$ uptake by the 'Massey Basyn' and Rotorua strains was greater than that of all other species. The Abbotsford strain was similar

TABLE 4: MEAN UPTAKE OF N AND P IN SHOOTS,+ ROOTS OF YORKSHIRE FOG (mg/pot)

\begin{tabular}{lll}
\hline & \multicolumn{1}{c}{$\mathbf{N}$} & \multicolumn{1}{c}{$P$} \\
\hline 'Massey Basyn' & $302 \mathrm{abAB}$ & $30.7 \mathrm{aAB}$ \\
Dipton & $287 \mathrm{abcAB}$ & $27.5 \mathrm{bcdABCD}$ \\
Abbotsford & $276 \mathrm{bcAB}$ & $29.6 \mathrm{abcABC}$ \\
Rotorua & $303 \mathrm{aA}$ & $31.8 \mathrm{aA}$ \\
Glen Innes & $309 \mathrm{aA}$ & $26.2 \mathrm{cdBC}$ \\
Almeida de Sayago & $209 \mathrm{dC}$ & $23.8 \mathrm{dD}$ \\
Stratford & $268 \mathrm{cB}$ & $25.2 \mathrm{dCD}$ \\
Tara Hills & $198 \mathrm{dC}$ & $24.4 \mathrm{dD}$ \\
\multicolumn{1}{c}{ c v $\%$} & 15.46 & 20.12 \\
\hline
\end{tabular}


to these two and to the Dipton and Glen Innes strains. Uptake of $\mathrm{P}$ by Almeida de Sayago, Stratford and Tara Hills strains was low.

The level of applied $\mathrm{N}$ 'affected $\mathrm{P}$ uptake. This effect was evident in the strain difference $\mathbf{x} \mathrm{N}$ interaction. The difference between 'Massey Basyn' and Tara Hills strains (Fig. 1 (d)) was linear $(\mathrm{P}<0.05)$ and took the form of a lower uptake of $\mathrm{P}$ by the Tat-a Hills strain in the absence of applied N. Uptake of $\mathrm{P}$ by 'Massey Basyn' did not change according to the level of $\mathrm{N}$ applied. The Rotorua and Stratford strain differences exhibited a similar interaction $(\mathrm{P}<0.05)$ and is shown in Fig. 1 (e) In this- interaction the uptake of $\mathrm{P}$ by the Rotorua strain was greater under the <intermediate and high level of applied $\mathrm{N}$.

The level of applied P affected P uptake of the Rotorua compared with the Stratford strain (Fig. 1 (f)). This interaction was linear $(P<0.05)$ with the former giving increasing uptake relative to the Stratford strain as the level of applied P increased. This may not be clear from the figure, but is apparent in the data where the slope of the difference between strains was +0.95 .

\section{EXPERIMENT B}

In this, experiment mean species and strain yields for shoots and shoots + roots are presented in Table 5. Under the Tara Hills climate, both strain's of Yorkshire fog gave higher yields than Ruanui perennial ryegrass, with 'Massey Basyn' outyielding the Tara Hills strain. Under both the Palmerston North and Taieri climates, Ruanui perennial ryegrass and 'Massey Basyn' Yorkshire fog gave similar yields. The Tare Hills strain was lower yielding $(\mathrm{P}<0.01)$ than the other two grasses. Species/strain yields of shoots and shoots + roots followed the same trend recorded for shoot yields under all climates.

Under the Tara Hills climate there was no significant interaction of species/strains and level of $\mathrm{N}$ applied, either in shoot or shoot and root yields. Thus yield efficiency did not vary with availability of soil $\mathrm{N}$. Under the Palmerston North climate there was a highly significant interaction both for shoot $(P<0.001)$ and shoot + root $(P<0.01)$ yields. Results for shoot yields are presented in Table 6 . These took the form of lower yields from the Tara Hills strain compared with Ruanui and 'Massey Basyn' at the lower levels of applied $\mathrm{N}$ but similar yields at the highest level of 'applied N. This means that the Tara Hills strain was inefficient in providing high yield's under low levels of available 
TABLE 5: MEAN YIELDS OF (a) SHOOTS, AND (b) SHOOTS + ROOTS OF PERENNIAL RYEGRASS AND YORKSHIRE FOG (logarithmic transformation of $\mathrm{g} / \mathrm{pot}$ )

\begin{tabular}{|c|c|c|c|}
\hline & \multicolumn{3}{|c|}{ Climate } \\
\hline & $\begin{array}{l}\text { Tara Hills } \\
\text { (Summer) }\end{array}$ & $\begin{array}{c}\text { Palmerston } \\
\text { North } \\
\text { (Spring) }\end{array}$ & $\begin{array}{c}\text { Taieri } \\
\text { (Winter) }\end{array}$ \\
\hline \multicolumn{4}{|l|}{ (a) Sноотs } \\
\hline Ruanui p.r. & $1.827 \mathrm{cC}$ & $1.482 \mathrm{aA}$ & $-1.011 \mathrm{aA}$ \\
\hline 'Massey Basyn’ Y.f. & $2.070 \mathrm{aA}$ & $1.718 \mathrm{aA}$ & $-1.281 \mathrm{abA}$ \\
\hline Tara Hills Y.f. & $1.938 \mathrm{bB}$ & $-0.539 \mathrm{bB}$ & $-1.472 \mathrm{bA}$ \\
\hline Lin. X Species Interaction & NS & $* * *$ & * \\
\hline Quad. x Species Interaction & NS & NS & NS \\
\hline $\mathrm{c} \mathrm{v} \%$ & 5.53 & 72.94 & 44.20 \\
\hline \multicolumn{4}{|l|}{ (b) SHоOTs + Roots } \\
\hline Ruanui p.r. & $2.563 \mathrm{cB}$ & 2. $248 \mathrm{aA}$ & $-0.550 \mathrm{abA}$ \\
\hline 'Massey Basyn' Y.f. & 2. $758 \mathrm{aA}$ & 2. $408 \mathrm{aA}$ & $0.815 \mathrm{bA}$ \\
\hline Tara Hills Y.f. & $2.649 \mathrm{bAB}$ & $0.034 \mathrm{bB}$ & - $0.855_{* * *} \mathrm{bA}$ \\
\hline Lin. X Species Interaction & NS & & \\
\hline Quad. x Species Interaction & NS & NS & NS \\
\hline $\mathrm{c} \mathrm{v} \%$ & 5.11 & 44.09 & 78. 37 \\
\hline
\end{tabular}

nitrogen. Under the Taieri climate, yields showed an actual depression for all grasses as the level of $\mathrm{N}$ was increased. There were significant interactions for shoot $(P<0.05)$ and shoot + root $(P<0.05)$ yields. Again the two sets of data showed the same trend, where Ruanui outyielded both 'Massey Basyn' and Tara Hills strains of Yorkshire fog under low levels of applied $\mathrm{N}$ but gave similar yields under high $\mathrm{N}$. Thus under the Taieri climate Ruanui appeared to be more efficient in providing high yields of dry matter than the Yorkshire fog strains. However, there is some doubt about the validity of results under the Teieri climate which will be dealt with in the discussion.

TABLE 6: INTERACTION OF SPECIES/STRAINS AND LEVEL OF $\mathrm{N}$ APPLIED ON SHOOT YIELDS UNDER THE PALMERSTON NORTH CLIMATE

(logarithmic transformation of $\mathrm{g} / \mathrm{pot}$ )

\begin{tabular}{cccc}
\hline \multirow{2}{*}{$k g / h a N$} & Ruanui p.r. & $\begin{array}{c}\text { Massey Basyn' } \\
\text { Y.f. }\end{array}$ & Tara Hills Y.f. \\
\hline 0 & $1.18 \mathrm{aA}^{*}$ & $1.47 \mathrm{aA}$ & $-1.11 \mathrm{bB}$ \\
$\mathbf{5}$ & $1.38 \mathrm{aA}$ & $1.60 \mathrm{aA}$ & $-1.64 \mathrm{bB}$ \\
10 & $1.41 \mathrm{aA}$ & $1.70 \mathrm{aA}$ & $-\mathbf{2 . 2 8} \mathrm{bB}$ \\
$\mathbf{3 0}$ & $1.69 \mathrm{aAB}$ & $1.81 \mathrm{aA}$ & $0.91 \mathrm{abAB}$ \\
$\mathbf{6 0}$ & $1.73 \mathrm{aA}$ & $\mathbf{2 . 0 0} \mathbf{a A}$ & $1.44 \mathrm{aA}$ \\
\hline
\end{tabular}

*Duncan's notation (based on LSDs) to be read across rows. 
The concentration of $\mathrm{N}$ in the herbage (Table 7) shows, under the Tara Hills and Palmerston North climates, greatest concentratioas in Ruanui followed by Tara Hills and finally 'Massey Basyn'. Under the Taieri climate, the Tara Hills strain of Yorkshire fog contained higher concentrations of $\mathrm{N}$ than the other two grasses.

The mean species/strain uptake of $\mathrm{N}$ (for shoots + roots) (Table 8) was similar for all grasses except under the Palmerston North climate, where uptake was lower in the Tara Hills

TABLE 7: MEAN CONCENTRATION (\%) OF $N$ IN SHOOTS OF PERENNIAL RYEGRASS AND YORKSHIRE FOG

\begin{tabular}{llll}
\hline & & \multicolumn{3}{c}{ Climate } \\
\cline { 2 - 4 } & $\begin{array}{c}\text { Tara Hills } \\
\text { (Summer) }\end{array}$ & $\begin{array}{c}\text { Palmerston } \\
\text { N orth } \\
\text { (Spring) }\end{array}$ & $\begin{array}{r}\text { Taieri } \\
\text { (Winter) }\end{array}$ \\
\hline Ruanui p.r. & $3.041 \mathrm{aA}$ & $3.405 \mathrm{bcBC}$ & $3.902 \mathrm{bABC}$ \\
'Massey Basyn' Y.f. & $2.781 \mathrm{dC}$ & $3.254 \mathrm{dD}$ & $3.932 \mathrm{abAB}$ \\
Tara Hills Y.f. & $2,967 \mathrm{bcAB}$ & $3.832 \mathrm{aA}$ & $3.885 \mathrm{aA}$ \\
cv \% & 3.632 & 2.795 & 2.640 \\
\hline
\end{tabular}

\begin{tabular}{|c|c|c|c|}
\hline \multicolumn{4}{|c|}{$\begin{array}{l}\text { TABLE 8: MEAN UPTAKE OF N IN SHOOTS } \\
\text { PERENNIAL RYEGRASS AND YORKSHIRH } \\
\text { (logarithmic transformation of } \mathrm{mg} / \mathrm{pot} \text { ) }\end{array}$} \\
\hline & \multicolumn{3}{|c|}{ Climate } \\
\hline & $\begin{array}{c}\text { Tara Hills } \\
\text { (Summer) }\end{array}$ & $\begin{array}{l}\text { Palmerston } \\
\text { N orth } \\
\text { (Spring) }\end{array}$ & $\begin{array}{r}\text { Taieri } \\
\text { (Winter) }\end{array}$ \\
\hline Ruanui p.r. & $0.705 \mathrm{ab}$ & $0.680 \mathrm{aA}$ & $-1.457 \mathrm{a}$ \\
\hline 'Massey Basyn' Y.f. & $0.731 \mathrm{a}$ & $0.732 \mathrm{aA}$ & $-1.704 \mathrm{a}$ \\
\hline Tara Hills Y.f. & $0.730 \mathrm{a}$ & $-1.055 \mathrm{cC}$ & $-1.759 \mathrm{a}$ \\
\hline $\mathrm{c} \mathrm{v} \%$ & 19.572 & 310.440 & 43.361 \\
\hline
\end{tabular}

TABLE 9: INTERACTION OF SPECIES/STRAINS AND LEVELS OF $\mathrm{N}$ APPLIED ON $\mathrm{N}$ UPTAKE UNDER THE PALMERSTON NORTH CLIMATE (mg N/pot)

\begin{tabular}{cccc}
\hline$k g / h a N$ & Ruanui p.r. & 'M assey Basyn' & Tara Hills $Y . f$. \\
\hline 0 & $0.29 \mathrm{aA}^{*}$ & $0.30 \mathrm{aA}$ & $-1.61 \mathrm{bB}$ \\
5 & $0.40 \mathrm{aA}$ & $0.52 \mathrm{aA}$ & $-2.14 \mathrm{bB}$ \\
10 & $0.57 \mathrm{aA}$ & $0.64 \mathrm{aA}$ & $-2.33 \mathrm{bB}$ \\
30 & $0.82 \mathrm{aA}$ & $0.85 \mathrm{aA}$ & $-0.12 \mathrm{bB}$ \\
60 & $1.32 \mathrm{aA}$ & $1.35 \mathrm{aA}$ & $0.92 \mathrm{aA}$ \\
\hline
\end{tabular}

"Duncan's notation (based on LSDs) to be read across rows. 
strain. There was no species/strain interaction under the Tara Hills climate, indicating that all species/strains behaved in a similar manner as the level of $\mathrm{N}$ increased. Under the Palmerston North climate there was a significant interaction $(\mathrm{P}<0.05)$ (Table 9) in which the uptake of $\mathrm{N}$ by the Tara Hills strain was lower than the other two under low levels of applied $\mathrm{N}$. For the Taieri climate, in which mean uptake did not differ, there was a significant interaction $(P<0.05)$ in which Ruanui had a lower uptake of $\mathrm{N}$ than the Yorkshire fog strains under low levels of applied $\mathrm{N}$, but similar uptake at high levels of $\mathrm{N}$.

\section{DISCUSSION}

In Experiment A 'Massey Basyn' and to a lesser extent Rotorua strains were the highest yielding. Thesa strains were also among those providing the greatest uptake of $\mathrm{N}$ and $\mathrm{P}$, suggesting a greater ability to extract 'available $\mathrm{N}$ and $\mathrm{P}$ from the soil than that of other strains. These strains also contained higher concentrations of $\mathrm{N}$ and $\mathrm{P}$. Should the reciprocal of percentage concentration be considered $\rightarrow$ i.e., dry matter per $100 \mathrm{~g}$ nutrient taken up the plant - one obtains a good index of efficiency of utilization of absorbed $\mathrm{P}$ within the plant. In the case of 'Massey Basyn' and Rotorua strains, their high $\mathrm{N}$ and $\mathrm{P}$ concentrations indicate low efficiencies of utilization of absorbed $\mathrm{N}$ and " $\mathrm{P}$.

The yield response of 'Massey Basyn' and Rotorua strains in comparison with other strains did not differ according to level of $\mathrm{N}$ or $\mathrm{P}$ applied. This suggests that the mean yield superiority of these strains is genetically based and operates through their abilities to extract greater amounts of $\mathrm{N}$ and $\mathrm{P}$ from the soil an uptake sufficiently large to overcome their lower efficiency of utilization of absorbed $\mathrm{N}$ and $\mathrm{P}$.

There is evidence to show that 'Massey Basyn' (from the comparison with the Tara Hills strain) had a greater ability to take up $\mathrm{N}$ under high levels of soil $\mathrm{N}$. Although this was not reflected in significantly higher yields at high levels of $\mathrm{N}$, it should be noted that the difference in yield approached significance at the $5 \%$ level of probability.

In the comparison of $\mathrm{P}$ uptake between the Rotorua and Stratford strains, it was found that the former took up greater amounts of $\mathrm{P}$ with increasing levels of applied $\mathrm{P}$. While this difference was not reflected in greater yields at high levels of applied $\mathrm{P}$, this does not preclude the possibility that a more precise experiment may have shown such an effect to be present and account for the high mean yields of the Rotorua strain. 
There is little doubt that the low yields of Almeida de Sayago and Tara Hills were attributable to low uptake of $\mathrm{N}$ and $\mathrm{P}$. This uptake was too low to be compensated for by greater efficiency of utilization of $\mathrm{N}$ (as shown by lower concentrations in the herbage) or in the case of applied P by greater efficiency of utilization of absorbed $P$.

The inability of the Tara Hills strain (in the comparison with 'Massey Basyn') to absorb $\mathrm{N}$ at high levels of applioatian is likely to have contributed to its low mean yields: similarly for Almeida de Sayago - as judged from the comparison with Glen Innes. The low mean yields from the Stratford strain could have been in part a reflection of its low uptake of $\mathrm{P}$ under high levels of applied $\mathrm{P}$ as shown by the comparison with the Rotorua strain.

Results from Experiment $B$ will be first discussed by examining the differences 'between the two strains of Yorkshire fog 'Massey Basyn' and Tara Hills. The high yielding characteristics of 'Massey Basyn' compared with Tara Hills strains noted in Experiment A was reproduced in Experiment B under the Tara Hills and Palmerston North climates and approached significance $(P<0.05)$ under the Taieri climate. The pattern of these differences according to level of $\mathrm{N}$ applied differed according to climate. Under the Tara Hills and Taieri climate they both responded in the same relative manner to increasing levels of applied N, while under the Palmerston North climate higher yields from 'Massey Basyn' were a reflection of its greater ability to respond to low levels of available soil $\mathrm{N}$. This finding does not 'appear to have been a reflection of greater experimental precision in the experiment under the Palmerston North climate, as the coefficient of variability was considerably higher than under the other two climates.

There is conflict in the results of $\mathrm{N}$ concentrations in shoots between the experiments. In Experiment A the Tara Hills strain contained lower concentrations than 'Massey Basyn', whereas in Experiment $B$ the situation was reversed. No explanation can be offered for this difference. It doles, however, leave the question of efficiency of utilization of absorbed $\mathrm{N}$ by the two strains in doubt.

$\mathrm{N}$ uptake differed between strains only under the Palmerston North climate and provides a ready explanatioa for the yield difference's recorded under this climate. The difference, in which 'Massey Basyn' had greater mean uptake of $\mathrm{N}$ than the Tara Hills strain, agrees with the findings of Experiment A. Further, the lower uptake of $\mathrm{N}$ by the Tara Hills strain in the presence of 
low levels of applied $\mathrm{N}$ under the Palmerston North climate agrees well with the yield data. It can be concluded that 'Massey Basyn' had the ability to take up greater amounts of $\mathrm{N}$ at low levels of soil $\mathrm{N}$, resulting in greater yield responses.

Where there is conflict in results, as noted earlier, it is difficult to make generalizations. It can only be concluded that the reason for the yield superiority of 'Massey Basyn' compared with the Tara Hills strain is unresolved but that their relative respoase to the level of $\mathrm{N}$ applied may vary according to climate.

For purposes of this discussion results obtained from Ruanui perennial ryegrass (the main ryegrass sown in New Zealand) will be compared with those from the highest yielding Yorkshire fog ('Massey Basyn'). Under two climates - namely, Palmerstoe North (spring) and Teieri (winter) - both gave comparable yields and under the Tara Hills climate (summer) 'Massey Basyn' outyielded Ruanui. These high yields from 'Massey Basyn' compared with Ruanui perennial ryegrass are in agreement with results of field experiments (Watkin and Robinson, 1974) and in accord with the high growth rates reported by Mitchell (1956) with an unspecified ecotype of Yorkshire fog.

The superiority of 'Massey Basyn' under the Palmerston North climate could be due to any of the differences in environmental parameters constituting this climate. From the work of Mitchell (1956), who examined the effects of constant temperature, there is evidence to show that the rate of growth of Yorkshire fog relative to Ruanui was greater at 18 " C than at 7 and 29" C. This, then, would suggest that temperature conditions under the Palmerston North climate approached bhe optimum! for Yorkshire fog. Soil moisture, which was the only other variable between the Palmerston North and Tara Hills environments, could also have contributed to this yield difference, but this experiment does not enable a differentiation to be made between the contributions from temperature and soil moisture.

Ruanui and 'Massey Basyn' did not enter into any interaction of yield according to level of $\mathrm{N}$ applied under either the Tara Hills or Palmerston North climates. Under the Taieri climate an interaction was recorded in which 'Massey Basyn' gave markedly lower yields than Ruanui under low levels of applied N. This result should be accepted with some caution as the growth curves both showed marked declines as the level of applied $\mathrm{N}$ was increased. It is considered that this was due to the drastic change in environment that occurred when plants were transferred from the heated glasshouse to the climate room. 
The high concentration of $\mathrm{N}$ in the herbage of Ruanui indicates a lesser ability to utilize absorbed $\mathrm{N}$ and as total uptake was similar for both grasses it appears that the high yielding characteristic of Yorkshire fog was associated with better utilization of absorbed $\mathrm{N}$. The absence of any interaction between these two in terms of uptake of $\mathrm{N}$ according to level of applied $\mathrm{N}$ indicates equal efficiency in uptake irrespective of amount of $\mathrm{N}$ applied.

\section{ACKNOWLEDGEMENTS}

The authors wish to thank the Director, Plant Physiology Division, DSIR, and the Room Allocation Committee for making climate controlled facilities available. They also wish to acknowledge the helpful advice of Prof. B. R. Watkin, Massey University and Dr R. A. Jackman, Grasslands Division, DSIR, and P. Nes, Grasslands Division, DSIR, for the chemical analysis of a number of the samples. The assistance of Dr G. H. Jowett and P. D. Johnstone, Invermay Agricultural Research Centre, Ministry of Agriculture and Fisheries, with the statistical analyses is also gratefully acknowledged.

\section{REFERENCES}

Anon., 1971: Rep. Soil Conserv. Auth. Vist.: 30.

Burnett, T. D., 1927: Natural History of Canterbury. (Eds. Speight, R. Wall, A.; Laing, R. M.). Simpson \& Williams, Christchurch.

Davies, W., 1940: Welsh J. Agric., 16: 175.

Dunhar, G. A., 1971: Proc. N.Z. ecal. Soc.. 18: 48.

Dunbar, G. A.; Adams, S. N., 1972: Proc. N.Z. Grassld Ass., 34: 129.

During, C.; Cullen, N. A.; Bennett, G. M., 1962: N.Z. $J l$ agric. Res., 5: 278.

Harlan, J. R., 1956: Theory and Dynamics of Grassland Agriculture. Van Nostrand, New Jersey.

Hughes, R.; Nicholson, I. A., 1961: J. Br. Grassld Soc., 16: 210.

Hunt, I. V., 1964: J. Br. Grassld Soc., 19: 55.

Jacques, W. A., 1962: Proc. N.Z. Grassld Ass., 24: 139.

McMeckan, C. P.; Walshe, M. J., 1963: J. agric. Sci., Camb., 61: 147.

Miles, J.; Miles. A. M., 1978: Rep. Nat. Conserv. 1968-69: 28-30.

Mitchell, K. J., 1956: N.Z. /l Sci. Tech., 38A: 203.

O'Connor, K. F., 1961: N.z. Il agric. Res., 4: 709.

Saxby, S. H., 1956: Pasture production in New Zealand. N.Z. Dept Agric. Bull. 250.

Smith, A., 1972: In Spedding, C. R. W.; Diekmahns, E. C., Grasses and legumes in British agriculture. Commonw. Bur. Pastures \& Field Crops Bull. 49.

Watkin, B. R.; Robinson, G. B., 1974: Proc. N.z. Grassld Ass., 36: 278-83.

White, J. G.; Meijer, G.; Langer, R. H. M., 1972: Proc. N.Z. Grassld Ass., 34: 139.

Whittet, J. N., 1964: Postures. The Farmer's Handbook Series. Department of Agriculture, N.S.W. 